\section{Heat illness}

\author{
PAF Hunt, JE Smith
}

"Commanding Officers of volunteers are very apt to err in this particular; and the spirit of their men is such that they shrink from complaint, and persevere in efforts which may easily, under a burning sun, become dangerous to life." Lancet, 10 June 1865 (1).

\section{Introduction}

Heat illness is caused by a rise in body core temperature, sustained from either intrinsic or extrinsic sources, or both. In its most severe form, homeostatic thermoregulatory mechanisms are overwhelmed causing an unchecked rise in body temperature and subsequent multi-organ dysfunction. Despite improvements in the knowledge and understanding of the aetiology and physiology of heat illness, it continues to be a significant cause of morbidity and mortality among members of the Armed Forces.

The term heat illness can be used to describe a wide spectrum of disease ranging from minor heat cramps to lifethreatening heatstroke. Exertional heat illness affects mainly athletes and military personnel, and therefore, military medical personnel need to be fully conversant with its prevention, recognition and treatment. A high index of clinical suspicion is required to make the diagnosis of heat illness and it should be suspected in any patient with signs of central nervous system dysfunction under conditions of heat stress.

This article aims to review the epidemiology, pathophysiology and relevant aspects of management including prevention, acclimatisation and treatment. As exertional heat illness is the predominant form affecting military personnel, it will be the primary focus of this review.

\section{Definitions}

Hyperthermia occurs as a consequence of excessive heat gain, excessive heat production, diminished heat dissipation, or a combination of all three. When normal heat dissipation mechanisms are overwhelmed the body core temperature will rise, and if this continues unchecked heat illness may occur.

Classical or environmental heat illness $(\mathrm{CHI})$ is commonest in those whose thermoregulatory control mechanisms are ineffi- cient or attenuated, such as the very young, elderly, those with important co-morbidities or those taking drugs that inhibit thermoregulation. The main contributing factor to the development of $\mathrm{CHI}$ is a high environmental temperature, with clusters of cases known to occur following heat waves and during large public gatherings in hot climates, such as the annual Hajj pilgrimage (2-7). Classical heat illness has also been termed non-exertional heat illness (NEHI) (8).

In contrast, exertional heat illness (EHI) typically affects young athletes or military personnel, whose rise in core temperature originates from significant muscular exercise, producing heat in such quantities that they are unable to dissipate it. This produces a typical clinical and pathological syndrome which, if allowed to continue unchecked will progress to heatstroke.

The definition of heatstroke is a matter of some confusion and controversy. It has been defined in the recent literature as a core temperature elevated above the range $39-41^{\circ} \mathrm{C}$ $\left(102.2-105.8^{\circ} \mathrm{F}\right)$ with associated central nervous system dysfunction (9-18). An important problem with defining heatstroke in terms of body core temperature criteria is that cooling has often been instituted before reaching a medical facility, so that by the time an accurate reading has been recorded it may have already fallen within, or near to, normal limits. More usefully heatstroke has been defined as "a form of hyperthermia associated with a systemic inflammatory response leading to a syndrome of multiorgan dysfunction in which encephalopathy predominates" (10). Exertional heatstroke in particular could be described as "a characteristic clinical and pathological syndrome due to extreme hyperthermia, that occurs when excess heat generated by muscular exercise exceeds the body's ability to dissipate it" (19).

Drug-induced hyperthermia following drug ingestion such as amphetamine or 3,4methylenedioxymethamphetamine (MDMA /"ecstasy"), malignant hyperthermia (MH) and neuroleptic malignant syndrome (NMS) all create similar clinical syndromes to EHI, but the underlying pathophysiologies are distinct from EHI. Detailed discussion regarding these conditions is not within the scope of this review though the potential contribution to, or exacerbation of, heat illness should be considered where these are suspected. 


\section{Epidemiology}

One of the earliest recorded descriptions of heat illness is to be found in the Old Testament in the Apocrypha, Judith 8 verses 2 and 3. The Arabs named the condition siriasis after Sirius, the dog star, which follows the sun in the summer months. Heat illness has affected military campaigns throughout the centuries, including the Roman campaign in Arabia in 24 BC during which a large part of the army perished due to the heat $(16,20)$.

Significant numbers of deaths due to heatrelated illness have been recorded in British military personnel since the 18th Century (21-24). However, the overall number of soldiers admitted to hospital with heat-related illness is usually far greater with only the worst cases reaching hospital, while many more were treated within their own regiments in the field by combat medical technicians and medical officers. Recent reviews of the numbers of British Armed Forces personnel admitted to hospital with heat-related illnesses revealed an average of 135 each year for the period 1981-1991 with 11 deaths during this time and 516 admissions in total (an average of 103 per year) during the five-year period from 1993-1997 (14,25). The reported incidence of heat injury in US basic military training facilities is typically around $5-8$ cases per 10,000 troops per week (26). The true incidence of heat-related illness may be much higher, especially on operations, due in part to underreporting bias and a lack of uniformity in case definition $(2,10,27,28)$.

\section{Pathophysiology}

Humans maintain a constant body temperature through a number of different physiological mechanisms including vasomotor alterations in blood flow and volume distribution, shivering and sweating. Highly sensitive peripheral and hypothalamic heat receptors stimulate the hypothalamic thermoregulatory centres which then send an efferent response via the autonomic nervous system to promote cutaneous vasodilatation and hence increase the delivery of blood to the skin (2931). Therefore, the normal physiological response of a healthy individual results in a hyperdynamic circulation with decreased peripheral resistance. Heat is normally lost through a combination of conduction, convection, radiation and evaporation of sweat as illustrated in Figure 1. Maximal thermoregulatory capacity depends on individual factors such as acclimatisation, pre-existing medical conditions and the use of certain drugs, and environmental factors including ambient temperature, humidity and wind speed. Mechanisms of thermoregulation and the autonomic regulation of blood pressure and cellular metabolism are usually in balance. Development of heat illness reflects a loss of this balance to the extent that such 'normal' physiological mechanisms become pathological (32).

At a cellular level, direct thermal injury causes damage by several mechanisms, including denaturation and inactivation of enzymes, disturbances of cellular lipid membranes and alterations to normal chemical bonds. Widespread tissue changes are largely due to sustained elevation of body temperature above that at which reversible cellular changes occur. Cellular metabolism is affected at temperatures above $42^{\circ} \mathrm{C}\left(107.6^{\circ} \mathrm{F}\right)$ and tissue damage is certain at temperatures above $46^{\circ} \mathrm{C}\left(114.8^{\circ} \mathrm{F}\right)$ (33). Circulatory insufficiency and hypoxia are the main secondary factors which contribute to more widespread cellular injury and organ dysfunction (30). The complex inter-relationship of possible factors on the development of heat illness is described in Figure 2 and a summary can also be found in Smith, 2004 (34).

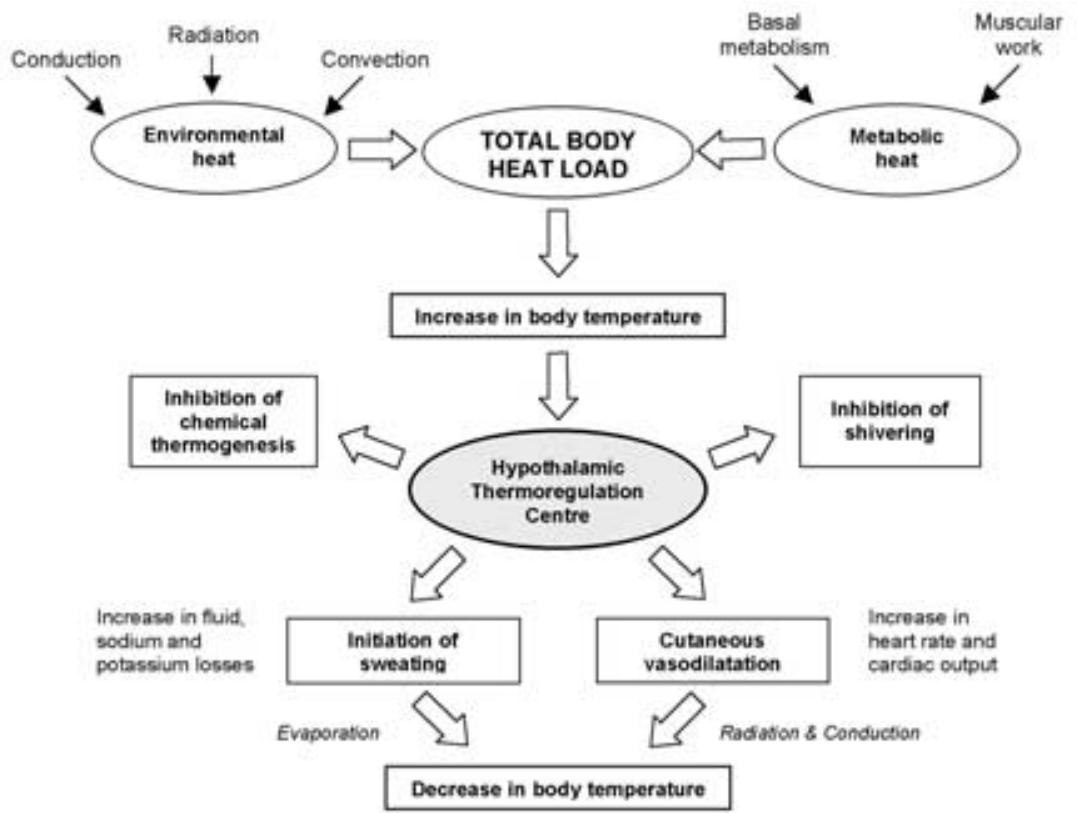

Fig 1. Normal physiological responses to heat loading. 


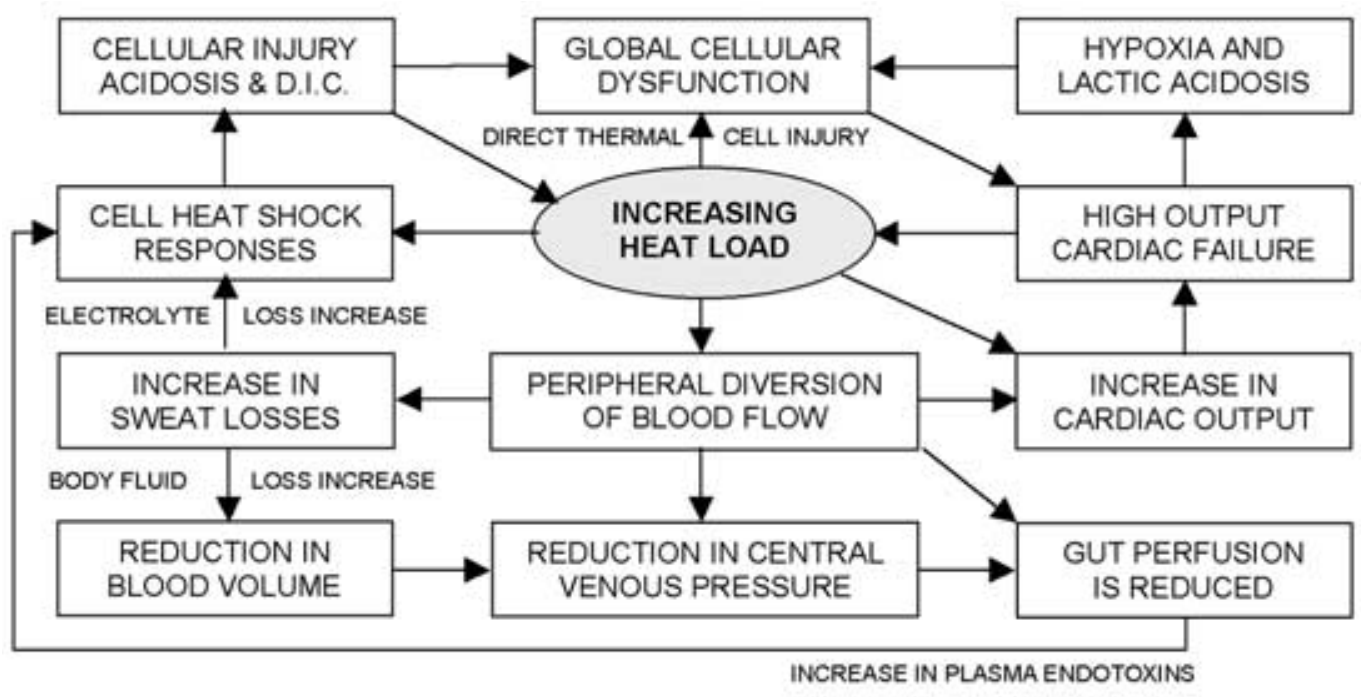

Fig 2. Abnormal pathophysiological responses occuring with loss of normal thermoregulation.

The question of why one individual should collapse with heat illness while others in the same environment remain unaffected is still not clear. Although many plausible theories exist the truth probably lies somewhere between them all. Considerable variation is seen in the response to heat strain between individuals and, because hyperthermia is not painful (in fact patients may even exhibit euphoria or similarly altered behaviour), heat exposure is often sustained even as the risk of heat illness increases (35). Several clear risk factors have been identified, and it may be that a combination of these factors render the susceptible individual more likely to suffer an episode than others. The main individual factors are extremes of age, co-morbidities, concurrent medications or alcohol and the level of physicial conditioning including cardiovascular fitness and obesity. Other factors include dehydration, inadequate acclimatisation to a hot climate, lack of sleep and excessive or restrictive clothing $(8,10,12,17,18,30,33,36-40)$. Table 1 summarises those conditions associated with an increased risk of heat illness and Table 2 lists those medications thought to have a role in the development or exacerbation of heat illness.

Table 1. Pre-existing conditions implicated in the development or exacerbation of heat-related illness.

\begin{tabular}{|l|l|}
\hline Agitation states & Hyperthyroidism \\
\hline Anorexia & Miliaria \\
\hline $\begin{array}{l}\text { Cardiovascular } \\
\text { disease }\end{array}$ & Obesity \\
\hline $\begin{array}{l}\text { Cerebrovascular } \\
\text { disease }\end{array}$ & $\begin{array}{l}\text { Peripheral vascular } \\
\text { disease }\end{array}$ \\
\hline $\begin{array}{l}\text { Concurrent viral } \\
\text { illness/sepsis }\end{array}$ & $\begin{array}{l}\text { Poorly controlled } \\
\text { hypertension }\end{array}$ \\
\hline Cystic fibrosis & $\begin{array}{l}\text { Poorly controlled } \\
\text { diabetes mellitus }\end{array}$ \\
\hline Diabetes & $\begin{array}{l}\text { Sickle cell trait/ } \\
\text { disease }\end{array}$ \\
\hline $\begin{array}{l}\text { Extensive cutaneous } \\
\text { burns }\end{array}$ & Scleroderma \\
\hline
\end{tabular}

Table 2. Classes and examples of drugs implicated in the development or exacerbation of heat-related illness.

\begin{tabular}{|l|l|}
\hline Anticholinergics & Diuretics \\
\hline Antihistamines & Ethanol \\
\hline Amphetamines & $\begin{array}{l}\text { Inhaled } \\
\text { anaesthetics }\end{array}$ \\
\hline $\begin{array}{l}\text { Anti-parkinsonian } \\
\text { drugs }\end{array}$ & LSD, PCP \\
\hline $\begin{array}{l}\text { Alpha--adrenergic } \\
\text { agonists }\end{array}$ & Laxatives \\
\hline $\begin{array}{l}\text { Beta- adrenergic } \\
\text { antagonists }\end{array}$ & Neuroleptics \\
\hline Benzodiazepines & Phenothiazines \\
\hline $\begin{array}{l}\text { Calcium channel } \\
\text { blockers }\end{array}$ & Thyroid hormones \\
\hline Cocaine & $\begin{array}{l}\text { Tricyclic } \\
\text { antidepressants }\end{array}$ \\
\hline
\end{tabular}

A previous episode of heat illness has been shown to increase the risk of future episodes due to hypothalamic dysfunction with unstable, and sometimes permanent, alterations to normal thermoregulatory mechanisms $(8,17,18,30,33,38,41,42)$. There may also be evidence of a genetic or inherent physiological predisposition thought to be related to the underlying mechanisms involved in malignant hyperthermia (43-45). There is little doubt that the use of heavy equipment or clothing (e.g. personal protection equipment and combat body armour) will have a direct impact on the ability to lose heat from the body $(8,17,30,38)$ and this is of particular relevance to military personnel.

\section{Prevention}

Preventative measures include the provision of adequate education and training, distribution of advice regarding the nature and risks of heat-related illnesses, pre-acclimatisation, limitation of heat exposure and metabolic heat loading, appropriate clothing and equipment modifications, adequate fluid and salt intake and the avoidance of predisposing drugs 
$(10,17,18,28,36,30)$.

Risk factors for heat-related illness may be divided into group and individual factors and all unit commanders and team leaders should be familiar with these in order to minimise heat casualties. Group factors are shared as a result of local environmental conditions, the type and level of activity and the type of clothing and protective equipment required for the work involved. These include fatigue and sleep deprivation, lack of food and water, inadequate acclimatisation, environmental heat and humidity and protective equipment such as body armour or nuclear-biological-chemical (NBC) suits. Individual risk factors include increasing age, a low level of physical fitness, obesity, concurrent illness, and some medications as outlined above. Studies of male military personnel in the US Marine Corps during basic training identified the major risk factors of exertional heat illness to be a raised BMI and poor level of physical fitness (40). Hot environments are generally hostile to individuals arriving from temperate climates. A good level of physical fitness, adequate heat acclimatisation and proper hydration are the best means of reducing the likelihood of developing heat-related illness (32).

Acclimatisation is the term given for the physiological response to a new environment or climate (46). The main adaptation noted with acclimatisation is an increase in sweating thought to occur as a result of an increased sensitivity and lower temperature threshold for the onset of sweating $(8,17,30,35,47-49)$. Sweating enhances skin cooling, therefore increasing the temperature gradient for core heat loss and subsequently an improvement in heat transfer efficiency. The intravascular fluid volume also expands leading to a reduced cardiovascular response required for an increased demand in cutaneous blood flow, thereby also improving cardiovascular efficiency $(35,50)$.

The term pre-acclimatisation refers to a period of pre-deployment cardiovascular training or artificial heat stress exposure by a number of different methods. Lack of adequate pre-acclimatisation to hot climates has been shown to be a risk factor for development of heat-related illness in military personnel upon deployment from temperate regions (51). These major physiological adaptations usually occur within the first week of regular heat exposure $(8,17)$ though full acclimatisation may require up to two months of regular heat exposure $(30,33)$. For practical purposes, the greatest adaptations and physiological benefits are seen following the first 10-14 days.

Protective clothing is a prime target for improvement in order to reduce the risk of heatrelated illness in individuals working in hot environments. It is vital that clothing meets strict ergonomic and physical requirements so that protection and function is maintained whilst minimising compromise from additional physiological or psychological strain (52). The use of short-sleeved shirts and short trousers may seem a reasonable measure in order to reduce heat gain in hot and humid environments. However, radiant heat from the sun may in fact increase total heat load in these circumstances (53). Skin exposure may also increase the dangers of ultraviolet light leading to sunburn in the short term and increased risk of skin cancer in the long term. For this reason, light-coloured and lightweight clothing with long sleeves and long trousers is advisable in hot and humid conditions where exposure to sun radiation is significant. Loosefitting clothing helps to allow more efficient evaporation and hence cooling (28).

Environmental heat can be measured in a number of ways and examples are shown in Table 3. These measurements can be combined by various algorithms in order to produce a number of different heat stress indices. Examples include the 'Oxford Index', 'Effective Temperature', 'Predicted Heat Strain', and 'Required Sweat Rate'. The most widely used, and most appropriate for military use, is the Wet Bulb Globe Temperature (WBGT) Index which combines the outdoor measurements of wet bulb, dry bulb and globe temperatures in weighted proportions. However, it should be stressed that WBGT measurements are only one part of the risk assessment for heat illness and other factors such as work intensity, clothing and rest periods must also be taken into account. Guidelines for recommended workloads for acclimatised and unacclimatised personnel at different WBGT levels can be found in Joint Services Publication (JSP) 539 (54).

Table 3. Different measures of environmental heat.

\begin{tabular}{|l|l|}
\hline Measure & Description \\
\hline Dry bulb temperature & Air temperature \\
\hline Wet bulb temperature & $\begin{array}{l}\text { Air temperature } \\
\text { taking into account } \\
\text { surface evaporation } \\
\text { of water }\end{array}$ \\
\hline Globe temperature & $\begin{array}{l}\text { Indicates radiant } \\
\text { heat load }\end{array}$ \\
\hline $\begin{array}{l}\text { Partial pressure of } \\
\text { water vapour in air }\end{array}$ & $\begin{array}{l}\text { The moisture } \\
\text { content of air }\end{array}$ \\
\hline $\begin{array}{l}\text { Saturated water } \\
\text { vapour pressure }\end{array}$ & $\begin{array}{l}\text { The maximum } \\
\text { possible moisture } \\
\text { content of air at a } \\
\text { particular } \\
\text { temperature }\end{array}$ \\
\hline Relative humidity & $\begin{array}{l}\text { Ratio of partial } \\
\text { pressure of water } \\
\text { vapour in air to the } \\
\text { saturated water } \\
\text { vapour pressure }\end{array}$ \\
\hline $\begin{array}{l}\text { Wet bulb globe } \\
\text { temperature }\end{array}$ & $\begin{array}{l}\text { Combined } \\
\text { temperature index } \\
\text { calculated as single } \\
\text { estimate of } \\
\text { environmental heat } \\
\text { stress }\end{array}$ \\
\hline
\end{tabular}


Table 4. The spectrum of heat related illness.

\begin{tabular}{|l|l|l|l|}
\hline Definition & Mild & Moderate & Severe \\
\hline $\begin{array}{l}\text { Commonly used } \\
\text { nomenclature } \\
\text { and } \\
\text { subclassification }\end{array}$ & $\begin{array}{l}\text { Heat oedema } \\
\text { Heat cramps } \\
\text { Heat tetany } \\
\text { Heat syncope }\end{array}$ & $\begin{array}{l}\text { Heat fatigue } \\
\text { Heat exhaustion }\end{array}$ & Heat stroke \\
\hline $\begin{array}{l}\text { Evidence of raised } \\
\text { core temperature }\end{array}$ & $\begin{array}{l}\text { Unlikely } \\
\text { Temporary }\end{array}$ & $\begin{array}{l}\text { Likely } \\
\text { Temporary }\end{array}$ & $\begin{array}{l}\text { Likely } \\
\text { Sustained }\end{array}$ \\
\hline $\begin{array}{l}\text { Hospital } \\
\text { admission } \\
\text { required }\end{array}$ & Rarely & Possible & Certain \\
\hline $\begin{array}{l}\text { Morbidity and } \\
\text { mortality }\end{array}$ & Low risk & Medium risk & High risk \\
\hline
\end{tabular}

\begin{tabular}{|c|c|c|c|}
\hline \multirow[b]{3}{*}{ Neurological } & Cardiovascular & Pulmonary & \\
\hline & \multirow{3}{*}{ 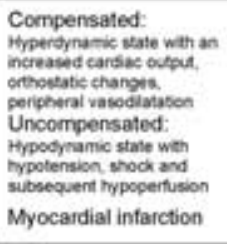 } & \multirow{3}{*}{$\begin{array}{l}\text { Hyperventiation } \\
\text { leading to respiratory } \\
\text { alkalosis } \\
\text { Pulmonary cedema } \\
\text { with water overload } \\
\text { Acule Respiratory } \\
\text { Distress Syndrome } \\
\text { Pulmonary intarction }\end{array}$} & \\
\hline & & & Renal \\
\hline \multirow{3}{*}{ 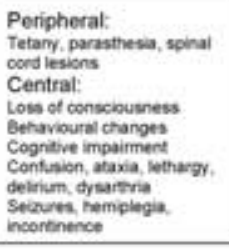 } & & & $\begin{array}{l}\text { Acute renal failure } \\
35 \% \text { Exertional } \\
5 \% \text { Non-exertional }\end{array}$ \\
\hline & Haematological & Biochemical & $\begin{array}{l}\text { Acute renal tubular } \\
\text { necrosis may occur }\end{array}$ \\
\hline & \multirow{3}{*}{$\begin{array}{l}\text { Pro-thrombotic state: } \\
\text { Cloting activation } \\
\text { Morovascular thrombess } \\
\text { Secondary forinoyvis } \\
\text { Reduced clotting } \\
\text { factors and platolots } \\
\text { Disseminated } \\
\text { Intravascular } \\
\text { Coagulation }\end{array}$} & \multirow{3}{*}{$\begin{array}{l}\text { Hypokalaemia and } \\
\text { later hyperkalaemia } \\
\text { Hypophosphataemia, } \\
\text { hypocalcaemia, } \\
\text { hypornagnesaemia } \\
\text { Initially respiratory } \\
\text { alkalosis then } \\
\text { metabolic acidosis }\end{array}$} & $\begin{array}{l}\text { Petechial } \\
\text { haemorrhages }\end{array}$ \\
\hline $\begin{array}{c}\text { Hepatic \& } \\
\text { Gastrointestinal }\end{array}$ & & & $\begin{array}{l}\text { Metabolic \& } \\
\text { Endocrine }\end{array}$ \\
\hline \multirow{3}{*}{$\begin{array}{l}\text { Hepatocellular } \\
\text { degeneration } \\
\text { Cholestasis } \\
\text { Raised serum Iver } \\
\text { function tests } \\
\text { Hepatocellular } \\
\text { necrosis } \\
\text { GI hvpoperfusion }\end{array}$} & & & \multirow{4}{*}{$\begin{array}{l}\text { Increased } \\
\text { carbohydrate } \\
\text { motabolism } \\
\text { Hyperglycaerria } \\
\text { Hypertactaerria } \\
\text { Increased secretion: } \\
\text { Sthess hormones including } \\
\text { catecholamines and cortio }\end{array}$} \\
\hline & $\begin{array}{l}\text { Neuromuscular } \\
\& \text { Cutaneous }\end{array}$ & Immunological & \\
\hline & \multirow{2}{*}{$\begin{array}{l}\text { Muscle fatigue and } \\
\text { reduced performance } \\
\text { Muscle cramps } \\
\text { Rhabdomyolsis } \\
\text { Increased sweating } \\
\text { with later antydrosis } \\
\text { as shock develops }\end{array}$} & \multirow{2}{*}{$\begin{array}{l}\text { Increased stress } \\
\text { hormone and pro- } \\
\text { inflammatory cytokine } \\
\text { release } \\
\text { Attenuated immune } \\
\text { responses } \\
\text { Increased later } \\
\text { incidence of sepsis }\end{array}$} & \\
\hline & & & \\
\hline
\end{tabular}

Fig 3. Summary of the pathophysiological manifestations of heat illness.

\section{Clinical Features}

The spectrum of heat illness ranges from minor heat rash or heat oedema to more severe heat exhaustion and ultimately lifethreatening heatstroke (Table 4). These symptom complexes represent a continuum of disease severity rather than discreet disease processes. Central nervous system manifestations are seen in all cases of significant heat illness as the brain is extremely sensitive to hyperthermia and hypoxia. Any individual experiencing symptoms such as cramps, agitation, nausea or vomiting, dizziness, staggering or loss of coordination, confusion, collapse or loss of consciousness during exposure to heat stress should be suspected of suffering from heat illness and receive immediate emergency assessment and treatment as appropriate.

The presentation of significant heat illness is usually acute. However, a proportion of patients may have prodromal symptoms last- ing several hours (28). Evidence suggests that there is considerable variation in the susceptibility to heat injury between individuals, in the same individual at different times and between different organ systems (55). A major pitfall in the diagnosis of clinically significant heat illness is a low level of clinical suspicion especially in the context of apparently mild environmental conditions. Certainly, delay in recognition and misdiagnosis seems to occur more commonly in moderate climates when suspicion is low (28). This is illustrated by a case series of 82 patients (56) where $30 \%$ of cases occurred in the spring, and many cases occurred at night or in the early morning.

Heat illness may affect many organ systems, as outlined in Figure 3. Complications can include arrhythmias, convulsions, shock, disseminated intravascular coagulation, renal failure and neurological impairment. Mortality rates from heatstroke have been quoted as high as $10 \%(31)$.

An important differential diagnosis to heat illness in hot climates is water intoxication. Excessive intake of hypotonic solutions or water during strenuous exertion in hot environments may lead to hyponatraemia. With a significant and rapid drop in sodium levels (usually below $130 \mathrm{mmol} / \mathrm{L}$ ) cerebral oedema will begin to develop, resulting in altered behaviour, changes in level of consciousness and later seizures, coma and death. Unfortunately, the early signs of exercise-induced hyponatraemia may be difficult to distinguish from that of heat illness (57-60). Features that may help differentiate heat illness from water intoxication are summarised in Table 5.

\section{Management}

The management of heat illness is summarised in Figure 4. It should include stopping the activity, removing the patient to an area of shade and reassessing risk for the rest of the group. For the individual patient, an assessment of airway, breathing and circulation should be the priority, and basic life support instituted if appropriate. The patient should be stripped and cooling measures initiated. High flow oxygen should be administered when available. Intravenous access should be obtained, and an infusion of crystalloid commenced (avoiding solutions that contain potassium such as Hartmanns solution). Initial observations should include a rectal temperature.

Once in an appropriate medical facility, the blood glucose should be measured and a urine dipstick test performed. The patient should be catheterised and fluid balance carefully monitored. Laboratory analysis of urea and electrolytes, liver function tests, creatine kinase, clotting, arterial blood gases and urinalysis should be undertaken. Fluid replacement must be tailored to the clinical and haemodynamic state of the individual as 
Table 5. Differentiation between heat illness and water intoxication signs and symptoms (from $57,58,61)$.

\begin{tabular}{|l|l|l|}
\hline & Heat Illness & Water intoxication \\
\hline Core temperature rise & In severe cases & Uncommon \\
\hline Resting pulse rate & Elevated & Normal \\
\hline Blood pressure & $\begin{array}{l}\text { Hypotensive } \\
\text { or normal }\end{array}$ & Normal or elevated \\
\hline Orthostatic changes & Decrease & No decrease \\
\hline $\begin{array}{l}\text { Urine output and } \\
\text { frequency }\end{array}$ & Oliguric $>4$ hrly & Polyuria <4hrly \\
\hline History of fluid intake & Varied & Usually increased \\
\hline Response to cooling & Gradual recovery & No improvement \\
\hline Behavioural alterations & In severe cases & Common \\
\hline Mucosal appearance & Usually dry & Moist \\
\hline $\begin{array}{l}\text { Symptoms and signs } \\
\text { common to both } \\
\text { conditions }\end{array}$ & $\begin{array}{l}\text { Nausea \& vomiting, headache, dizziness, } \\
\text { fatigue, disorientation, confusion, ataxia, } \\
\text { seizures }\end{array}$ \\
\hline
\end{tabular}

a policy of routine aggressive rehydration may result in pulmonary oedema or metabolic disruption. Central venous pressure and invasive arterial monitoring should be considered, and patients transferred to an appropriate critical care environment depending on the severity of their condition.

Many authors suggest that the major determinant of outcome in heatstroke is the duration and severity of hyperthermia $(6,8,10,17,18,28,33,35,36,62,63)$. A retrospective case series found a trend towards improved survival in patients cooled to a core temperature below $38.9^{\circ} \mathrm{C}$ within 60 minutes (62), and another report found improved survival when patients were cooled to the same level within 30 minutes (6). Evidence therefore, supports the imperative that core temperature is reduced as quickly as possible. Cooling should be achieved at a rate of around $0.5^{\circ} \mathrm{C}\left(0.9^{\circ} \mathrm{F}\right)$ every 5 minutes. Due to the lag phase in recording, once the core body temperature falls to below $39^{\circ} \mathrm{C}$ $\left(102.2^{\circ} \mathrm{F}\right)$, active cooling should cease in order to avoid overcorrection and hypothermia $(8,10,18,28,30,35,36,64)$.

The best method of cooling remains a controversial issue $(17,18,33,63)$. Routine unit or departmental protocols and regular training for medical personnel involved are important in order to improve the speed and efficiency of cooling measures (18). The aim of cooling therapy is to increase the core-to-peripheral temperature gradient and hence maximise heat loss.

Ice-water immersion has been shown to be a highly effective method for rapid lowering of core body temperature $(30,35,63)$. However, cool water immersion is also understood to be similarly efficacious and may offer several advantages over ice-water immersion (18). Practical and tactical considerations make immersion methods unfeasible in all but a few cases and most hospitals and emergency departments are not equipped for this procedure. The main disadvantages are patient and attendant discomfort, induced shivering, difficulty with patient monitoring equipment and resuscitation efforts (making safe defibrillation almost impossible) (5,8, $17,18,33,36)$. An effective alternative to full body immersion is to place only the patient's hands and feet in cold water (65).

Evaporative cooling involves spraying the body with tepid water and blowing air over the skin surface $(5,8,10,28,33,36,64)$. This is the recommended technique for use by military personnel and is termed the STRIPSPRAY-FAN method.

Invasive methods of cooling may involve peritoneal dialysis with cold fluids, cold water gastric, pleural or bladder lavage, use of cooled intravenous fluids or cardiopulmonary bypass in extreme cases where more conservative measures have failed $(5,17$, 18,33). New devices for intravascular cooling have been designed for use in specific conditions in critical care units (66) though the use of these has yet to be studied formally in heat illness.

Despite the implication of pyrogenic cytokines in the development of heat illness, antipyretics such as aspirin, paracetamol or non-steroidal anti-inflammatory drugs (NSAID's) are not thought to have a useful role in the acute management of heat-related illness and may in fact exacerbate renal and hepatic dysfunction or worsen coagulopathies $(8,10,18,33,35)$. No other pharmacological agent has yet been identified and proven to accelerate cooling and improve outcome in the treatment of severe heat-related illness. The use of dantrolene sodium is recommended in malignant hyperthermia and suggested in neuroleptic malignant syndrome (67). However, there is no evidence that dantrolene has any additional benefit over standard cooling methods in heat illness $(5,8,10,36,68)$

Urinary alkalinisation with sodium bicarbonate and diuresis with low doses of intravenous furosemide $(1 \mathrm{mg} / \mathrm{kg})$ or mannitol $(0.25 \mathrm{mg} / \mathrm{kg})$ may promote renal blood flow, helping to prevent precipitation of myoglobin in the renal tubules and damage from hyperuricaemia $(5,8,10,18,28,30,36)$. However, there is some evidence to suggest that this is no better than adequate fluid administration alone (8). Early dialysis may be required in acute renal failure as indicated by anuria, severe uraemia or hyperkalaemia $(18,28,33)$ though may be ineffective in severely catabolic states (30). Resistant hyperkalaemia may require the use of potassiumlowering resins or an insulin-dextrose infusion $(5,36)$.

The management of significant clotting abnormalities is also controversial and there may be a significant delay in the diagnosis of DIC (28). The most important step is to treat the underlying hyperthermia with rapid cooling measures. Administration of whole blood, fresh frozen plasma (FFP), cryoprecipitate or platelet concentrates in coagu- 


\section{Heat illness treatment guidelines}

Immediate Action:

- High index of suspicion (to recognise signs early)

- STOP the activity of all (and assess others for signs).

- Airway/Breathing/Circulation.

- Shade.

- Undress

- COOL with water \& Fan.

- Lie down/Elevate legs.

- Oral fluids, if conscious.

- Oral glucose, if conscious.

- Call for assistance (999).

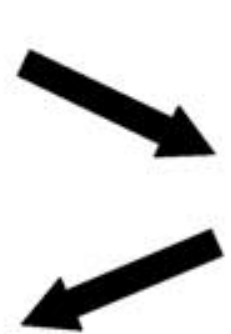

Initial 'Medic' Assistance (Medic on scene):

- Check Airway/Breathing/Circulation.

- RECTAL temperature.

- Clinical Observations (Pulse/Resn/Consciousness level).

- IV Access (1-2 litres isotonic crystalloid - normal saline

[avoid Hartmans]).

- Maintain cooling procedure.

Possible role for IV Glucose ( $50 \mathrm{ml}$ Glucose $50 \%)$

- If seizures oceur: prone position.

$-100 \%$ Oxygen, when available.

On arrival at Medical Centre/Primary Care Treatment Facility:

- Check Airway/Breathing/Circulation, - Check RECTAL. temperature

- Continue with cooling (Water and fanning).

- More detailed clinical observations (for example including ECG).

- 100\% Oxygen.

- IV Access, if not previously established.

- Blood Glucose check.

- Be aware of risk of seizures and treat as required.

- Clinical review: assess and review need for transfer.

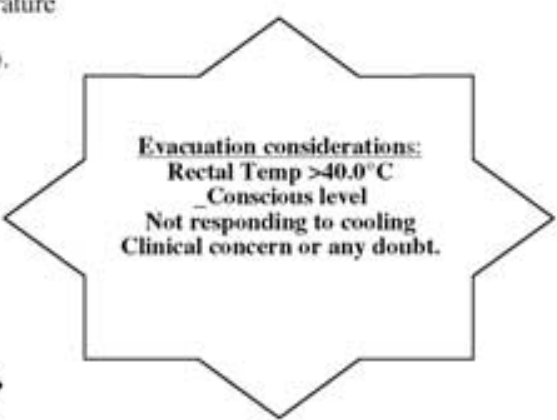

Hospital Emergency Care:

- Airway/Breathing/Circulation - as above

- Continue with cooling.

- Rectal temperature on arrival

- Confirm previous treatment - Continue triage and care:

' $\mathrm{A}$ ' - Consider intubation and ventilation

$\cdot{ }^{\prime}{ }^{\prime}-100 \%$ Oxygen

" $\mathrm{C}$ " - IVI and IV Fluids. Assess fluid balance

'D' - Assess consciousness level (Glasgow Coma Scale)

'E' - Urinary catheter/NG tube/CVP line/Arterial line

- Investigations: FBC, U+Es, L.FTs (bilirubin, AST,

ALT), CK, clotting sereen, myoglobin clearance,

blood gases and lactate.

- Consider alkalinisation.

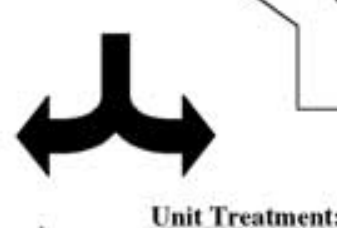

Unit Treatment:

(If Hospital Care option not taken):

- Confirm casualty is fully conscious and alert:

- Keep bedded down for $24-48$ hrs.

- Continue with observations (urinalysis and visual check).

- Monitor fluid balance.

- Investigations

(FBC, U+Es, serum osmolality, LFTs, CK, elotting screen).

- Check blood sugar levels.

- Twice daily urinalysis and visual check for 2 days.

- MO review at days $3,5,7$ and 10 .

Fig 4. Heat illness treatment guidelines (54).

lopathies has proven successful in some case reports $(5,18,28,30)$.

Acid-base abnormalities are usually corrected by cooling, hydration and oxygen therapy though severe acidosis may be treated with aliquots of sodium bicarbonate in carefully calculated doses depending on blood gas analysis $(5,28)$. Cerebral oedema may complicate severe heat illness and appropriate treatment should be instigated in order to reduce further secondary brain injury.

With the onset of severe heat illness, even rapid normalisation of body temperature may not be sufficient to prevent the inflammation cascade, onset of coagulation dysfunction and subsequent progression to multi-organ failure. New approaches to the modulation of inflammatory responses could provide future therapeutic avenues for treatment of severe heat-related illness. These may include the use of antibodies, inhibitors or binding agents to endotoxins and cytokines as well as the use of corticosteroids and interleukin-receptor antagonists. Replacement therapy with recombinant activated protein $\mathrm{C}$ has also shown promise in the treatment of severe sepsis, which has many pathological similarities to severe heat illness. The protective features of heat shock proteins and antibodies to endotoxins may also have a future role in pre- conditioning and illness prevention $(10,69,70)$.

\section{Follow-up}

Unfortunately, there is little definitive scientific evidence regarding when it is appropriate to return to normal activities in hot environments following a diagnosis of heat-related illness. An individual who has already sustained one episode of heat illness may be susceptible to the effects of increased heat loading for a variable length of time (54). With mild to moderate forms of heat-related illness the signs and symptoms usually resolve within days. However, considerable individual variation is seen with heat-related illnesses and standardised algorithms may not be appropriate for all. Advice should be offered regarding the avoidance of further heat stress and strenuous activity and maintaining adequate hydration for at least the first 48 hours, and definately until symptoms have fully resolved. Acclimatisation should be allowed to continue with a graded increase in activity level over time under careful medical supervision. The fundamental principles of prevention should be explained and the risks of further heat-related illness emphasised. Military personnel diagnosed with mild to moderate heat illness not requiring hospital admission, and without 
biochemical evidence of end-organ damage, should be instructed to avoid high environmental heat loads for around 1 to 2 weeks $(54,71)$. If admission to hospital is required, or there is biochemical evidence of organ damage without complication, medical teams should advise the cessation of strenuous exertion for one month and refer the patient to a specialist centre for further assessment (54). This may require a temporary change in medical catergory.

An increased susceptibility to further major heat illness is a feature in victims of severe heat-related illness. This may reflect permanently altered and unstable thermoregulatory mechanisms (33). However, temporary heat intolerance has also been described in individuals suffering from severe heat-related illnesses. Susceptibility to thermal stress was demonstrated initially in one such case but then was shown to have recovered on further testing four months later thus indicating a temporarily induced, rather than inherent, heat intolerance (72).

Severely affected individuals should be advised to avoid any future exposure to high environmental or metabolic heat loads. For military personnel this may require a permanent change in medical categorisation by a full medical board. Re-assessment should take place involving heat stress testing under controlled, medically supervised conditions in special facilities, such as the Heat Illness Clinic at the Institute of Naval Medicine (INM). Referrals should be made via the Administrative Officer of the Environmental Medicine Unit (AO/EMU), INM, Gosport, Hampshire, PO12 2DL (Tel: Mil 9380 68051, Civ 0239276 8051).

\section{Conclusion}

Heat illness is still a significant cause of morbidity among members of the Armed Forces on operational deployment and at home. We have learnt much about the physiology and prevention of heat illness, but there are still significant questions to be answered, in particular how to predict an individual's susceptibility to developing heat illness. The JSP 539 on climatic injuries presents the doctrinal approach to the prevention and treatment of heat-related illness (54). This gives definitive advice regarding prevention and treatment for both medical and non-medical staff. Practical documentation includes a risk assessment aide memoire, water requirement tables, heat illness investigation, treatment and rehabilitation protocols and heat illness reporting forms.

\section{Further reading}

In addition to the many review articles and research papers published in the wider literature, the following textbook is highly recommended for those wishing to expand upon the information and issues presented in this article.
Medical Aspects of Harsh Environments, Volume 1. KB Pandolf and RE Burr, Eds. Textbooks of Military Medicine. Washington, DC: Borden Institute, Office of the Surgeon General, US Army Medical Department, 2001. 609 pages. ISBN: 0-1605107-6.

\section{References}

1 Anonymous. Trained to death! Lancet 1865;1:627.

2 Ellis FP. Heat illness I. Epidemiology. Trans $R$ Soc Trop Med Hyg 1977;70(5/6):402-11.

3 Jones TS, Laing AP, Kilbourne EM, et al. Morbidity and mortality associated with the July 1980 heat wave in St Louis and Kansas City, Mo. $\mathcal{F A M A ~ 1 9 8 2 ; ~}$ 247(24):3327-31.

4 Ghaznawi HI, Ibrahim MA. Heat stroke and heat exhaustion in pilgrims performing the Haji (annual pilgrimage) in Saudi Arabia. Ann Saudi Med 1987;7:323-6.

5 Seraj ME. Heat stroke during Haji (pilgrimage) - an update. Middle East F Anaesth 1992;11(5):407-41.

6 Dematte JE, O'Mara K, Buescher J, et al. Near-fatal heat stroke during the 1995 heat wave in Chicago. Ann Intern Med 1998;129:173-81.

7 Easterling DR, Meehi GA, Parmesan C, et al. 2000. Climate extremes: observations, modeling, and impacts. Science 2000;298:2068-74.

8 Delaney KA. Heatstroke. Underlying processes and lifesaving management. Postgrad Med 1992; 91(4):379-88.

9 Cooper JK. Preventing heat injury: military versus civilian perspective. Mil Med 1997;162: 55-8.

10 Bouchama A, Knochel JP. Heat stroke. NEFM 2002;346(25):1978-88.

11 Duthie DJR. Heat-related illness. Lancet 1998; 352:1329-30.

12 Chung NK, Pin CH. Obesity and the occurrence of heat disorders. Mil Med 1996;161:739-42.

13 Donoghue ER, Graham MA, Jentzen JM, et al. Criteria for the diagnosis of heat-related deaths: National Association of Medical Examiners: position paper. Am f For Med Pathol 1997;18(1):11-14.

14 Dickinson JG. Heat illness in the services. F R Army Med Corps 1994;140:7-12.

15 Knochel JP, Reed G. Disorders of heat regulation. In: Narins RG, ed. Clinical disorders of fluid and electrolyte metabolism. 5th ed. New York: McGrawHill. 1994. 1549-90.

16 Bricknell MC. Heat Illness - a review of military experience (Part 1). J R Army Med Corps 1995; 141(3):157-66

17 Barrow MW, Clark KA. Heat-related illnesses. Am Fam Phys 1998;58(3):749-56.

18 Khosla R, Guntupalli KK. Heat-related illnesses. Crit Care Clin 1999;15(2):251-63.

19 Allsopp A. Treatment and prevention of heat illness: minutes from a one day workshop, 23 March 2002. Alverstoke: Institute of Naval Medicine; 2002.

20 Jarcho S. A Roman experience with heat stroke in 24 BC. Bull NY Acad Med 1967;43:767-68

21 McClean WC. Disease of Tropical Climates. Lectures at the Army Medical School London. Macmillan \& Co. 1886.

22 Simpson RJS. The 'effects of heat' during the South African War. F R Army Med Corps 1909;12: 243-263.

23 Mitchell TJ, Smith GM. Medical services. History of the Great War. Casualties and Medical Statistics. London: HMSO. 1931.

24 Shibolet S, Lancaster MC, Danon Y. Heat stroke: a review. Aviat Space Environ Med 1976;47,280-301.

25 Defence Council Instruction, Joint Service Publication 122. Heat Illness in the Armed Forces: Prevention and Treatment. HMSO. 2001.

26 Sonna LA. Chapter 9: Practical medical aspects of military operations in the heat. In: Medical Aspects of Harsh Environments, Vol. 1. Department of the Army: Office of The Surgeon General, Borden Institute. 2002. 293-309. 
27 Ellis FP. Mortality from heat illness and heat-aggravated illness in the United States. Environ Res 1972;5:1-58

28 Shapiro Y, Seidman DS. Field and clinical observations of exertional heat stroke patients. Med Sci Sports Exerc 1990;22(1):6-14.

29 Hensel H. Neural processes in thermoregulation. Physiol Rev 1973;53(4):948-1017.

30 Stine RJ. Heat illness. JACEP 1979; 8(4): 154-60.

31 Simon HB. Current concepts: hyperthermia. NEFM 1993;329(7):483-7.

32 Hales JR. Hyperthermia and heats illness. Pathophysiological implications for avoidance and treatment. Ann New York Acad Sci 1997;813:534-44.

33 Scott J. Heat-related illnesses. When are they a true emergency? Postgrad Med 1989;85(8):154-6.

34 Smith JE. The pathophysiology of exertional heatstroke. 7 R Nav Med Serv 2004;90(3):135-8.

35 Gaffin SL, Hubbard RW. Chapter 5: Pathophysiology of heatstroke. In: Medical Aspects of Harsh Environments, Vol. 1. Department of the Army: Office of The Surgeon General, Borden Institute. 2002. 161-208.

36 Wexler RK. Evaluation and treatment of heat-related illnesses. Am Fam Phys. 2002;65(11):2307-14.

37 Sprung CL. Heat stroke; modern approach to an ancient disease. Chest 1980;77(4):461-2.

38 Bricknell MC. Heat Illness - a review of military experience (Part 2). f R Army Med Corps 1996; 142(1):34-42.

39 Diaz J, Jordan A, Garcia R, et al. Heat waves in Madrid 1986-1997: effects on the health of the elderly. Int Arch Occ Environ Health 2002;75(3):163-70.

40 Gardner JW, Kark JA, Karnel K, et al. Risk factors predicting exertional heat illness in male Marine Corps recruits. Med Sci Sport Exerc 1996;28:939-44.

41 Shapiro Y, Magazanik A, Udassin R, et al. Heat intolerance in former heatstroke patients. Ann Intern Med 1979;90(6):913-6.

43 Noakes TD. Fluid and electrolyte disturbances in heat illness. Int $f$ Sports Med 1998;19(Suppl 2): S146-9.

44 Wappler F, Fiege M, Steingath M, et al. Evidence for susceptibility to Malignant Hyperthermia in patients with exercise-induced rhabdomyolysis. Anaesth 2001;94:95-100.

45 Porter AM. Collapse from exertional heat illness: implications and subsequent decisions. Military Medicine 2003;168(1):76-81.

46 Bligh J, Johnson KG. Glossary of terms for thermal physiology. F Appl Physiol 1973;35:941-61.

47 Henane R, Valatx JL. Thermoregulatory changes induced during heat acclimatization by controlled hyperthermia in man. 7 Physiol (London) 1973; 230:255-71.

48 Schvartz E, Bhattacharya A, Sperinde SJ, et al. Sweating responses during heat acclimation and moderate conditioning. F Appl Physiol 1979;46:67580.

49 Nielsen B. Heat stress and acclimation. Erg 1994; 37(1):49-58.

50 Senay LC, Mitchell D, Wyndham CH. Acclimatisation in a hot, humid environment: body fluid adjustments. F Appl Physiol 1976;40(5):786-96.

51 Ellis FP. Heat Illness. III. Acclimatization. Trans $R$ Soc Trop Med Hyg 1977;70(5-6):419-25.
52 Holmer I. Protective clothing and heat stress. Erg 1995;38(1):166-82.

53 Kato M, Ha M, Tokura H. Thermophysiological responses under the influences of two types of clothing at an ambient temperature of 32 degrees $\mathrm{C}$ with sun radiation. F Hum Erg 1997;26(1):51-9.

54 Defence Council Instruction, Joint Service Publication 539. Climatic Injuries in the Armed Forces: Prevention and Treatment. HMSO 2003. Chapter 2: Heat.

55 Ellis FP. Heat illness II. Pathogenesis. Trans $R$ Soc Trop Med Hyg 1977;70(5/6):412-8.

56 Epstein Y, Moran DS, Shapiro Y, et al. Exertional heat stroke: a case series. Med Sci Sport Exerc 1999;31:224-8.

57 Shopes EM. Drowning in the desert: exercise-induced hyponatraemia at the Grand Canyon. $\mathcal{F}$ Emerg Nurs 1997;23(6):586-90.

58 Garigan TP, Ristedt DE. Death from hyponatraemia as a result of acute water intoxication in an Army basic trainee. Mil Med 1999;164(3):234-8.

59 O'Brien KK, Montain SJ, Corr WP, et al. Hyponatraemia associated with overhydration in U.S. Army trainees. Mil Med 2001;166(5):405-10.

60 Gardner JW. Death by water intoxication. Mil Med 2002;167(5):432-4.

61 Backer HD, Shopes E, Collins SL. Hyponatraemia in recreational hikers in Grand Canyon National Park. FWild Med 1993;4:391-406.

62 Vicario SJ, Okabajue R, Haltom T. Rapid cooling in classic heatstroke: effect on mortality rates. $A m \mathcal{F}$ Emerg Med 1986;4:394.

63 Smith JE. Cooling methods used in the treatment of exertional heat illness. Br $\mathcal{F}$ Sports Med. 2005;39: 503-7.

64 Weiner JS, Khogali M. A physiological body cooling unit for treatment of heat stroke. Lancet 1980;1 507.

65 Clapp AJ, Bishop PA, Muir I, et al. Rapid cooling techniques in joggers experience heat strain. F Sci $\mathcal{E}$ Med Sport 2001;4(2):160-7.

66 Schmutzhard E, Engelhardt K, Beer R, et al. Safety and efficacy of a novel intravascular cooling device to control body temperature in neurologic intensive care patients: a prospective pilot study. Crit Care Med 2002;30(11):2481-8.

67 Ward A, Chaffman MO, Sarkin EM. Dantrolene. A review of its pharmacodynamic and pharmacokinetic properties and therapeutic use in malignant hyperthermia, the neuroleptic malignant syndrome and an update of its use in muscle spasticity. Drugs 1986;32:130-68

68 Bouchama A, Cafege A, Devol EB, et al. Ineffectiveness of dantrolene sodium in the treatment of heatstroke. Crit Care Med 1991;19:176-80.

69 Gaffin SL. Endotoxins in heatstroke. Lancet 1990; 335(8680):62.

70 Gaffin SL, Hubbard RW. Experimental approaches to therapy and prophylaxis for heat stress and heatstroke. Wild E Envir Med 1996;7(4):312-34.

71 Bricknell MC. Heat illness in the army in Cyprus. Occ Med 1996;46(4):304-12.

72 Keren G, Epstein Y, Magazanik, A. Temporary heat intolerance in a heatstroke patient. Aviat Space Environ Med 1981;52(2):116-7. 